https://doi.org/10.15407/scine16.04.074

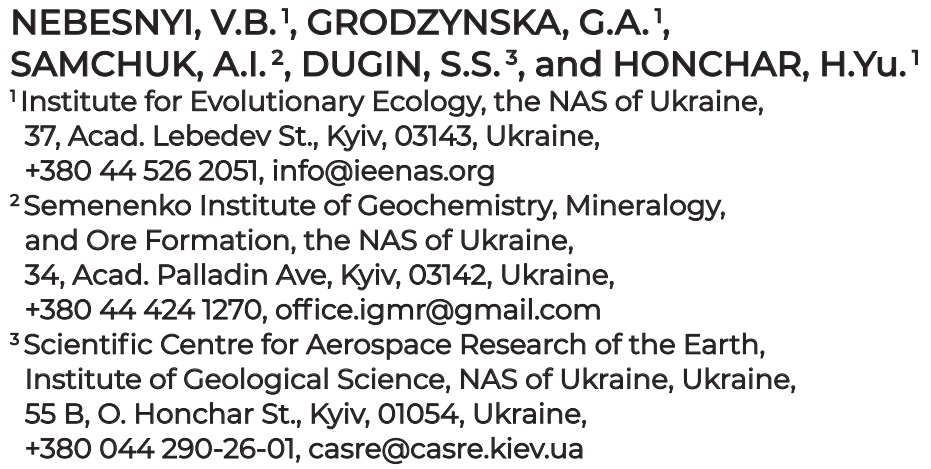

\title{
SPECTROPHOTOMETRIC EXPRESS METHOD IN BIOINDICATION OF PARK ECOSYSTEMS
}

Introduction. Park areas perform conservational and recreational functions in an urban environment that is under the influence of intense man-made load.

Problem Statement. The global decline in air quality, the augmentation of toxic emissions and industrial wastes, require constant monitoring of the environment, which must be focused primarily on biotic parameters.

Purpose. Estimation of the man-made pollution of park ecosystems of Kyiv according to the spectral characteristics of leaves of the bioindicator species Taraxacum officinale F.H. Wigg., and the content of heavy metals in them and in the soils.

Materials and Methods. Spectrophotometry method for studying the spectral characteristics of T. officinale leaves; induction-coupled plasma mass spectrometry (ICP-MS) method for measuring the content of $\mathrm{Cu}, \mathrm{Pb}, \mathrm{Zn}$, $\mathrm{Mn}, \mathrm{Ni}$, Cr in leaves and soils from localities; statistical methods.

Results. The average level of correlations $(0.50-0.69)$ between vegetation indices $R_{550} / R_{485}, R_{550} / R_{620}, R_{450}$ $R_{735}$, NDVI, RESV, SI and Cu content is shown, $\mathrm{Pb}, \mathrm{Mn}$ in leaves and $\mathrm{Pb}$ and $\mathrm{Mn}$ - in soils, and a high degree of correlation (0.75-0.87) between the indices $R_{450} / R_{733}, N D V I, R E S V$, LCI and the content of Zn and Cr in leaves and soils. There is a clear trend of increasing the content of heavy metals in the direction from the central parts of the park areas to the peripheral ones, which are intensively affected by traffic.

The most polluted is the Mariinsky Park. High levels of heavy metals $\mathrm{Cu}, \mathrm{Pb}$ and $\mathrm{Cr}$ were also found in the soils and leaves of the park of the Kyiv Polytechnic Institute. The lowest level of pollution is in the Feofaniya park.

Conclusions. The discussed vegetation indices are recommended both for rapid assessment of the state of natural and urban ecosystems, and for interpretation of satellite images for zoning and to determine the degree of man-made pollution. The use of the spectrophotometric method for bioindication is promising due to a high speed of obtaining results, a wide coverage, and a low cost.

Keywords: bioindication, heavy metals, park ecosystems, Taraxacum officinale F.H. Wigg., and spectral reflection.

Citation: Nebesnyi, V.B., Grodzynska, G.A., Samchuk, A.I., Dugin, S.S., and Honchar, H.Yu. Spectrophotometric Express Method in Bioindication of Park Ecosystems. Sci.innoz. 2020. V. 16, no. 4. P. 74-82. https:// doi.org/10.15407/scine16.04.074 
Parklands are an integral part of any urban landscape. It is a well-known fact that parks or "green areas" perform environmental, recreational, cultural, aesthetic, and sanitary functions [1]. At the same time, the global warming, an increase in air pollution and anthropogenic load, a decrease in the area of urban tree plantations have stressed the physiological state of plants and led to their contamination with pests and diseases $[2,3]$.

In addition, the dynamics of parkland development are affected by the synanthropization of flora, the expansion of urban development and transport infrastructure [4]. The urban environment that is changing under the influence of intense anthropogenic load impacts the objects of biota, which undergo physiological, morphologi$\mathrm{cal}$, anatomical, biochemical, and other transformations. This property of biological objects enables the effective use of their representatives for biotesting and bioindication of man-made pollution $[1,5]$.

Plants are reliable and representative bioindicators of environment pollution by various toxi- cants, as they are forced to adapt to stress through physiological, biochemical, anatomical, and morphological changes in their bodies. Today, developing methods for rapid diagnosis of the state of the urban environment using certain plant species and plant communities as bioindicators is a relevant problem.

Air and soil pollution results in changing pigment composition of plants, which manifests itself in changing spectral reflectance properties of the leaves. Numerous studies have proven the relationship between changes in the optical parameters and the physiological state of plants. In particular, the spectral reflectance of green leaves has been established to correlate with the level of their photosynthetic activity. Since photosynthesis is very sensitive to the influence of environmental factors, changes in its intensity can determine the plants response to stressors, including air pollution [6-11]. A comprehensive analysis of changes in these parameters may be a basis for developing methods for remote diagnosis of the state of urban ecosystems [9, 12-15].

\section{Table 1. Map of Sampling in the Parkland Sites in the City of Kyiv}

\begin{tabular}{|c|c|c|c|c|}
\hline Site & Place of sampling & Latitude & Longitude & $\begin{array}{l}\text { Altitude above the } \\
\text { sea level, } \mathrm{m}\end{array}$ \\
\hline \multicolumn{5}{|c|}{ Feofanya Park } \\
\hline I & Bus stop, $300 \mathrm{~m}$ from entrance to the park & $50^{\circ} 20^{\prime} 24^{\prime \prime}$ & $30^{\circ} 28^{\prime} 39^{\prime \prime}$ & 186 \\
\hline II & $50 \mathrm{~m}$ down from the entrance & $50^{\circ} 20^{\prime} 24^{\prime \prime}$ & $30^{\circ} 29^{\prime} 00^{\prime \prime}$ & 176 \\
\hline III & $30 \mathrm{~m}$ down from the administrative building at 37 Lebedev St. & $50^{\circ} 20^{\prime} 24^{\prime \prime}$ & $30^{\circ} 29^{\prime} 14^{\prime \prime}$ & 152 \\
\hline IV & $100 \mathrm{~m}$ from the pond No.3 & $50^{\circ} 20^{\prime} 21^{\prime \prime}$ & $30^{\circ} 29^{\prime} 25^{\prime \prime}$ & 139 \\
\hline \multicolumn{5}{|c|}{ KPI Park } \\
\hline I & Near the motorway, Peremohy Av. & $50^{\circ} 27^{\prime} 05^{\prime \prime}$ & $30^{\circ} 27^{\prime} 47^{\prime \prime}$ & 153 \\
\hline II & $60 \mathrm{~m}$ from the avenue, in the middle of the park slope & $50^{\circ} 27^{\prime} 03^{\prime \prime}$ & $30^{\circ} 27^{\prime} 42^{\prime \prime}$ & 160 \\
\hline III & On the slope, $20 \mathrm{~m}$ from the upper road & $50^{\circ} 27^{\prime} 02^{\prime \prime}$ & $30^{\circ} 27^{\prime} 37^{\prime \prime}$ & 164 \\
\hline IV & Near the right wing of building No. 1 & $50^{\circ} 27^{\prime} 02^{\prime \prime}$ & $30^{\circ} 27^{\prime} 34^{\prime \prime}$ & 165 \\
\hline \multicolumn{5}{|c|}{ Mariinskyi Park } \\
\hline I & Near the bus stop (opposite to the House of Officers) & $50^{\circ} 26^{\prime} 45^{\prime \prime}$ & $30^{\circ} 32^{\prime} 21^{\prime \prime}$ & 200 \\
\hline II & $50 \mathrm{~m}$ from the bus stop & $50^{\circ} 26^{\prime} 47^{\prime \prime}$ & $30^{\circ} 32^{\prime} 21^{\prime \prime}$ & 201 \\
\hline III & $\begin{array}{l}25 \mathrm{~m} \text { from the building of the Ministry of Healthcare of Ukraine } \\
\text { (MHCU) }\end{array}$ & $50^{\circ} 26^{\prime} 49^{\prime \prime}$ & $30^{\circ} 32^{\prime} 24^{\prime \prime}$ & 201 \\
\hline IV & $\begin{array}{l}\text { Backside of the administrative building of MHCU (beginning } \\
\text { of the slope) }\end{array}$ & $50^{\circ} 26^{\prime} 53^{\prime \prime}$ & $30^{\circ} 32^{\prime} 25^{\prime \prime}$ & 193 \\
\hline
\end{tabular}



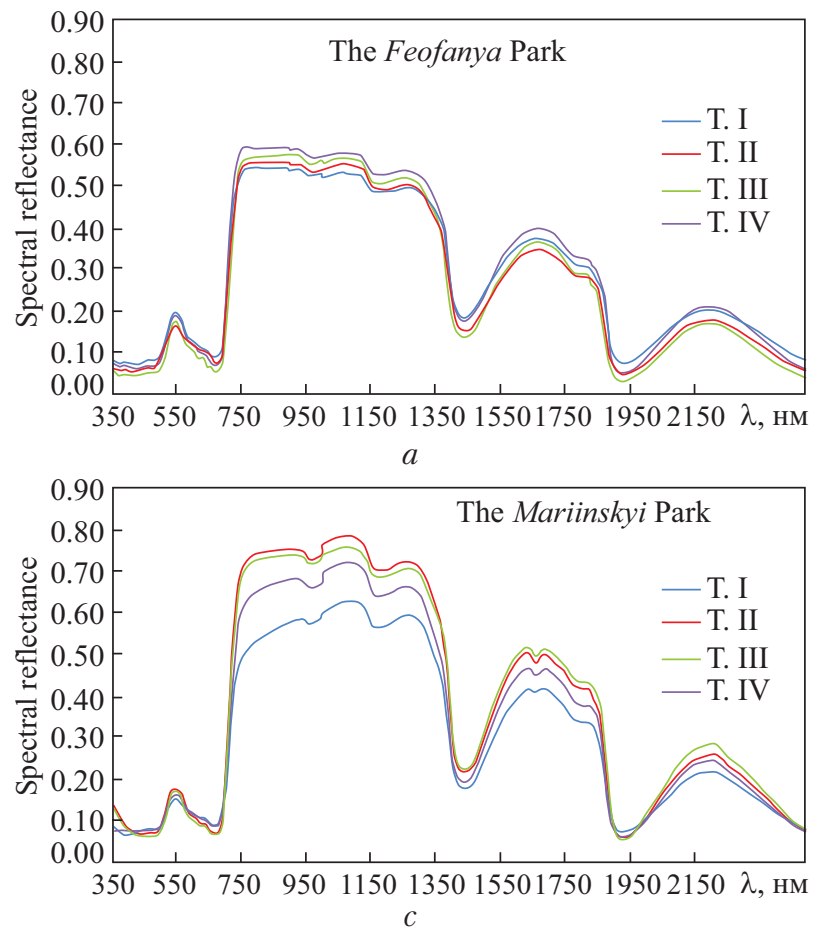

Dandelion (Taraxacum officinale F. H. Wigg.) as bioindicator has been used to assess a man-made impact on the environment condition of park areas in Kyiv. It is chosen for the reason of its wide spread, accessibility and a high sensitivity to many factors of antropogenic pollution [16-20].

The purpose of this research is to assess the manmade pollution of park ecosystems in Kyiv based on a comprehensive analysis of spectral reflectance parameters and content of heavy metals $\mathrm{Cu}$, $\mathrm{Pb}, \mathrm{Zn}, \mathrm{Mn}, \mathrm{Ni}$, and $\mathrm{Cr}$ in Taraxacum officinale leaves and soils from selected park sites.

The study was conducted in June 2018, on the territory of the three parks in Kyiv: Feofania Park, the park of Kyiv Polytechnic Institute (the KPI park), and the Mariinskyi Park located at different altitudes above the sea level and have different slope angles. In each park, four sites are selected (I, II, III, and IV). They are located at different distances from the roads towards the central part of the park area, where pollution is considered minimal (Table 1).

In each locality, 5 soil samples from the root layer $(0-5 \mathrm{~cm}$ deep) and 30 samples of $T$. offi-

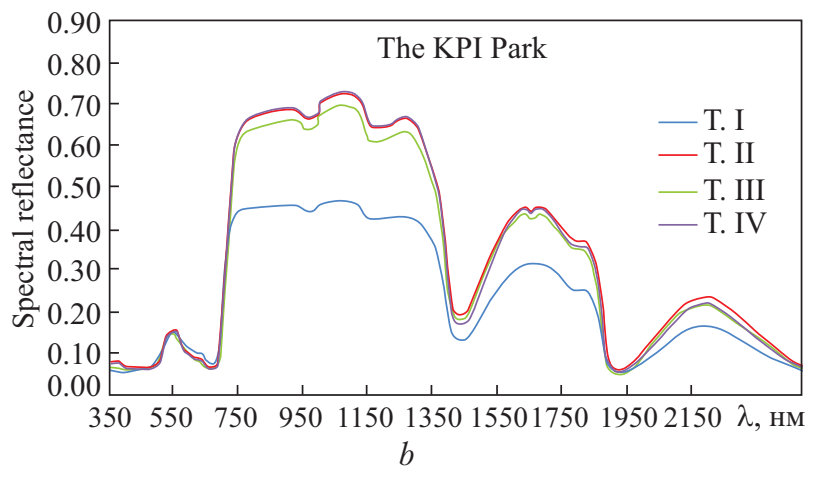

Fig. 1. Spectral reflectance of leaves of Taraxacum officinale FF.H. Wigg. from the sites of the Feofanya Park ( $a$ ), the KPI Park $(b)$ and the Mariinskyi Park (c)

cinale leaves are taken. The spectral reflectance properties of the leaves have been measured using a field portable spectroradiometer ASD FieldSpec ${ }^{\circledR} 3 F R$ (USA) having an operating spectral range from 350 to $2500 \mathrm{~nm}$. The data of 10-time measurements of each leaf have been automatically averaged, and the result is used to calculate the spectral reflectance (SR or $R$ ).

Among the variety of spectral vegetation indices, based on the analysis of literature sources and authors' previous research [13-15, 2125], 14 most informative ones have been selected (Table 2).

The content of heavy metals $\mathrm{Cu}, \mathrm{Pb}, \mathrm{Zn}, \mathrm{Mn}$, $\mathrm{Ni}$, and $\mathrm{Cr}$ in soil and leaf samples of the studied species has been measured by the mass spectrometry method with induction-coupled plasma, using an analyzer ICP-MS Element-2 (Germany) and the technique developed by O.M. Ponomarenko and co-authors [26].

About 1,800 leaf reflectance spectra have been obtained and analyzed for the leaves selected from 12 sites. The reflectance spectra of $T$. officinale leaves have clearly shown the presence of cont- 
rasts in individual spectral ranges between samples collected in different habitats (Fig. 1).

As expected, the most informative are the lines of absorption and reflection of solar energy by the main pigment complexes of plants, chlorophyll and carotenoids, in the visible region of the spectrum and its maximum reflection in the near infrared zone, which is associated with leaf cell structure. Spectral vegetation indices have been calcu-

\section{Table 2. Spectral Vegetation Indices}

\begin{tabular}{|c|c|}
\hline $\begin{array}{l}\text { Spectral vegetation } \\
\text { index* }\end{array}$ & $\begin{array}{c}\text { Index name and its physiological } \\
\text { interpretation }\end{array}$ \\
\hline $\begin{array}{l}R_{550} / R_{620} ; R_{500} / R_{620} \\
R_{550} / R_{485} ; R_{450} / R_{735} \\
R_{435} / R_{500} ; R_{435} / R_{620}\end{array}$ & $\begin{array}{l}\text { Heavy metal indices characterize their } \\
\text { content in the plant }\end{array}$ \\
\hline $\begin{array}{l}N D V I=\left(R_{800}-\right. \\
\left.-R_{670}\right) /\left(R_{800}+R_{670}\right)\end{array}$ & $\begin{array}{l}\text { Normalized vegetation index is a quantita- } \\
\text { tive indicator of phytomass photosyn- } \\
\text { thetic activity that minimizes the influ- } \\
\text { ence of lighting conditions, soil condi- } \\
\text { tions, leaf orientation, and meteorological } \\
\text { factors }\end{array}$ \\
\hline$V I=R_{800} / R_{670}$ & $\begin{array}{l}\text { Normal vegetation index characterizes } \\
\text { the condition and density of vegeta- } \\
\text { tion, neutralizes various effects of al- } \\
\text { bedo }\end{array}$ \\
\hline$S I=R_{550} / R_{800}$ & $\begin{array}{l}\text { Stress index (inverse vegetation index) } \\
\text { shows the degree of suppression of } \\
\text { plants (low SI values correspond to } \\
\text { more productive photosynthesis and, } \\
\text { accordingly, a better state of the eco- } \\
\text { system) }\end{array}$ \\
\hline $\begin{array}{l}R E S V=\left(\left(R_{718}+\right.\right. \\
\left.\left.\left.+R_{748}\right) / 2\right)-R_{733}\right)\end{array}$ & $\begin{array}{l}\text { Red edge stress index characterizes the } \\
\text { degree of physiological changes in } \\
\text { plants, depending on the influence of } \\
\text { stress factors }\end{array}$ \\
\hline $\begin{array}{l}H M=\left(R_{630} / R_{690}\right) / \\
\left(R_{520} / R_{600}\right)\end{array}$ & $\begin{array}{l}\text { Heavy metal accumulation index charac- } \\
\text { terizes the total accumulation of heavy } \\
\text { metals (primarily, iron) in plant leaves }\end{array}$ \\
\hline $\begin{array}{l}C I=\left(R_{750} / R_{710}\right)-1 \\
L C I=R_{695} / R_{760}\end{array}$ & $\begin{array}{l}\text { Chlorophyll index and leaf chlorophyll } \\
\text { index indicates the quantitative con- } \\
\text { tent of chlorophyll in leaves }\end{array}$ \\
\hline$P I=R_{430} / R_{680}$ & $\begin{array}{l}\text { Pigment index characterizes the state } \\
\text { of leaves pigment complex (primarily, } \\
\text { carotenoids and anthocyanins, which } \\
\text { are present in significant amount in } \\
\text { suppressed plants) }\end{array}$ \\
\hline
\end{tabular}

Note. ${ }^{*}$ - digit means value of SR for a certain wavelength, in $\mathrm{nm}$. lated based on SR measured in these parts of the spectrum.

The analysis of the spectral indices of T. officinale leaves from the localities of the studied parks (Fig. 2) has showed that the most informative of them are: NDVI, VI, SI, RESV, and $R_{450} / R_{735}$. Thus, NDVI and VI indices of sites located near

Table 3. Characteristics of Ecotopes of the Kyiv Parks in Terms of the Content of Heavy Metals in T. officinale $(L)$ and in the Soil $(S)$

\begin{tabular}{|c|c|c|c|c|c|c|}
\hline \multirow{2}{*}{ Site } & \multicolumn{6}{|c|}{ Content of heavy metals, mg/kg dry weight } \\
\hline & $\mathrm{Cu}$ & $\mathrm{Pb}$ & $\mathrm{Zn}$ & $\mathrm{Ni}$ & Mn & $\mathrm{Cr}$ \\
\hline \multicolumn{7}{|c|}{ Feofanya Park } \\
\hline$L_{\mathrm{I}}$ & 15 & 8 & 150 & 10 & 400 & 7 \\
\hline$S_{\mathrm{I}}$ & 50 & 50 & 500 & 40 & 600 & 50 \\
\hline$L_{\mathrm{II}}$ & 10 & 7 & 80 & 4 & 200 & 5 \\
\hline$S_{\text {II }}$ & 40 & 40 & 200 & 20 & 300 & 40 \\
\hline$L_{\mathrm{III}}$ & 10 & 4 & 80 & 4 & 250 & 4 \\
\hline$S_{\mathrm{III}}$ & 40 & 30 & 300 & 20 & 350 & 30 \\
\hline$L_{\mathrm{IV}}$ & 6 & 3 & 80 & 3 & 250 & 4 \\
\hline$S_{\mathrm{IV}}$ & 20 & 20 & 300 & 20 & 300 & 20 \\
\hline \multicolumn{7}{|c|}{ KPI Park } \\
\hline$L_{\mathrm{I}}$ & 80 & 10 & 800 & 8 & 300 & 8 \\
\hline$S_{\text {I }}$ & 300 & 100 & 3000 & 30 & 500 & 80 \\
\hline$L_{\mathrm{II}}$ & 50 & 5 & 100 & 5 & 180 & 3 \\
\hline$S_{\text {II }}$ & 100 & 60 & 300 & 20 & 350 & 10 \\
\hline$L_{\mathrm{III}}$ & 30 & 4 & 100 & 3 & 150 & 5 \\
\hline$S_{\mathrm{III}}$ & 60 & 40 & 300 & 10 & 300 & 30 \\
\hline$L_{\mathrm{IV}}$ & 30 & 7 & 200 & 4 & 170 & 6 \\
\hline$S_{\mathrm{IV}}$ & 50 & 80 & 500 & 20 & 350 & 40 \\
\hline \multicolumn{7}{|c|}{ Mariinskyi Park } \\
\hline$L_{\mathrm{I}}$ & 60 & 40 & 250 & 20 & 200 & 8 \\
\hline$S_{\mathrm{I}}$ & 500 & 300 & 1000 & 100 & 400 & 40 \\
\hline$L_{\mathrm{II}}$ & 30 & 5 & 130 & 10 & 300 & 3 \\
\hline$S_{\text {II }}$ & 200 & 60 & 450 & 30 & 350 & 10 \\
\hline$L_{\mathrm{III}}$ & 30 & 4 & 90 & 10 & 250 & 5 \\
\hline$S_{\text {III }}$ & 80 & 50 & 300 & 30 & 350 & 30 \\
\hline$L_{\mathrm{IV}}$ & 20 & 2 & 100 & 2 & 200 & 4 \\
\hline$S_{\mathrm{IV}}$ & 40 & 20 & 500 & 10 & 300 & 20 \\
\hline
\end{tabular}



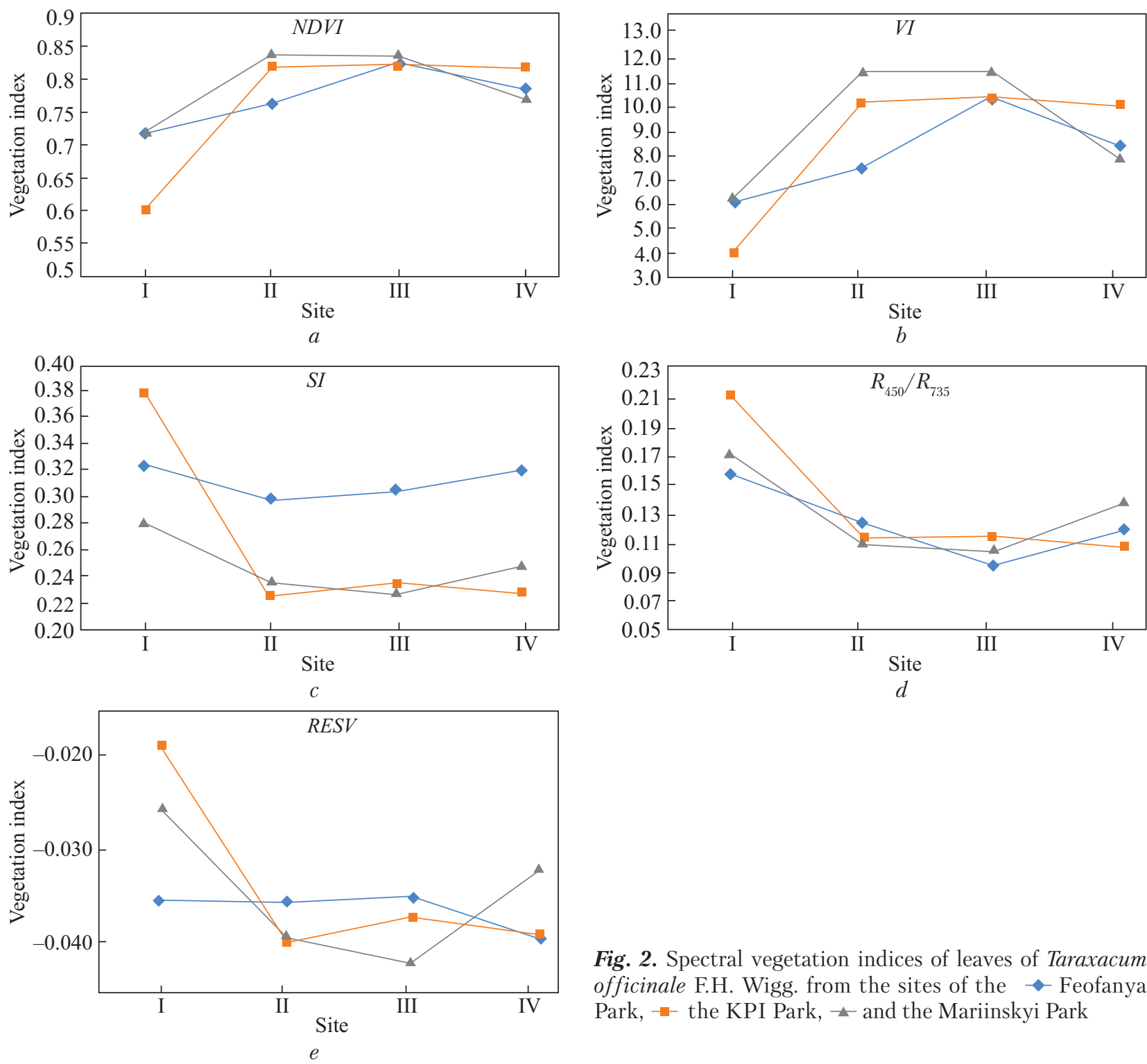

Fig. 2. Spectral vegetation indices of leaves of Taraxacum officinale F.H. Wigg. from the sites of the - - Feofanya Park, - the KPI Park, - - and the Mariinskyi Park

roads and motorways are much lower than those of the central parts of the park areas. The opposite relationship has been reported in the case of $S I, R E S V$, and $R_{450} / R_{735}$ indices. It should be noted that the values of indices vary (NDVI and VI decrease, while $S I, R E S V$, and $R_{450} / R_{735}$ increase) in sites IV of all parks, because of the internal roads in the KPI Park and in the Mariinskyi Park and the active recreation area of the Feofanya Park.

The spectral indices of $T$. officinale leaves from the Feofanya Park significantly differ from those

of other parks, which confirms the lowest anthropogenic load on its ecosystem.

The study of $T$. officinale leaves and soil samples from the park sites has shown that the highest content of heavy metals is found in sites I located near roads and public transport stops (Table 2). The most polluted is the Mariinsky Park situated on a plateau in the central (elevated) part of the city. Here, there has been detected a high content of $\mathrm{Cu}, \mathrm{Pb}, \mathrm{Zn}$ in soils and $\mathrm{Pb}$, $\mathrm{Zn}, \mathrm{Ni}$ in the leaves. A high content of heavy me- 
tals $\mathrm{Cu}, \mathrm{Pb}$, and $\mathrm{Cr}$ has been found in the soils and leaves from the KPI Park, as well. At the same time, an increased content of heavy metals in the samples from site IV is probably explained by its location near the academic building and the upper park road. The least polluted is the Feofanya park situated near the city boundary, some distance from motorways.

The studies of cesium-137 activity and the mineral composition of wild macromycetes from the Feofanya Park in 2015-2017 have reported a safe level of heavy metals in their fruiting bodies [27], which confirms a rather good ecological purity of this area. It should be noted that, in some cases, a high content of metals in the soil samples does not coincide with their content in the biomass of leaves. This phenomenon is apparently related to the presence of mobile forms of heavy metals in the soil-plant system.

The analysis of the reflectance spectra of $T$. officinale leaves from three park ecotopes in Kyiv and the content of heavy metals in leaves and soils from habitats has showed average correlations
(0.50-0.69) between the number of spectral indices: $R_{550} / R_{620} ; R_{550} / R_{485} ; R_{450} / R_{735} ; N D V I$; $R E S V, S I$ and the content of $\mathrm{Cu}, \mathrm{Pb}$, and $\mathrm{Mn}$ in the leaves and $\mathrm{Pb}$ and $\mathrm{Mn}$ in the soils from the root layer, and a high correlation $(0.75-0.87)$ between the spectral indices $R_{450} / R_{735} ; N D V I ; R E S V$; $L C I$ and the content of $\mathrm{Zn}$ and $\mathrm{Cr}$ in the leaves and soils (Table 4).

Modern approaches to environment assessment should focus primarily on biotic indicators. The use of remote sensing methods to assess the state of natural and urban ecosystems is quite promising due to a rapid obtainment of results, a broad coverage of territories and a low cost. Given that the proposed rapid method objectively shows the physiological state of plants in real time, it can be recommended for implementing in the network of stations for monitoring environment pollution at B. Sreznevsky Kyiv Central Geophysical Observatory that belongs to the State Environment Monitoring System.

Thus, correlations have been established between the optical parameters of T. officinale lea-

Table 4. Correlations between the Vegetation Spectral Indices and the Content of Heavy Metals in the Leaves of $T$. officinale $(L)$ and in the Soils $(S)$ from the Park Ecotopes of the City of Kyiv

\begin{tabular}{|c|c|c|c|c|c|c|c|c|c|c|c|c|}
\hline \multirow{3}{*}{$\begin{array}{l}\text { Spectral } \\
\text { index }\end{array}$} & \multicolumn{12}{|c|}{ Metal content in the samples } \\
\hline & \multicolumn{2}{|c|}{$\mathrm{Cu}$} & \multicolumn{2}{|c|}{$\mathrm{Pb}$} & \multicolumn{2}{|c|}{$\mathrm{Zn}$} & \multicolumn{2}{|c|}{$\mathrm{Ni}$} & \multicolumn{2}{|c|}{$\mathrm{Mn}$} & \multicolumn{2}{|c|}{$\mathrm{Cr}$} \\
\hline & $L$ & $S$ & $L$ & $S$ & $L$ & $S$ & $L$ & $S$ & $L$ & $S$ & $L$ & $S$ \\
\hline$R_{550} / R_{485}$ & -0.646 & -0.575 & -0.516 & -0.534 & -0.573 & -0.586 & -0.455 & -0.460 & -0.115 & -0.501 & -0.673 & -0.514 \\
\hline$R_{550} / R_{620}$ & -0.566 & -0.571 & -0.553 & -0.527 & -0.649 & -0.674 & -0.381 & -0.461 & -0.142 & -0.502 & -0.735 & -0.671 \\
\hline$R_{500} / R_{620}$ & 0.322 & 0.199 & 0.114 & 0.178 & 0.034 & 0.033 & 0.305 & 0.176 & 0.096 & 0.263 & 0.133 & -0.114 \\
\hline$R_{450} / R_{735}$ & 0.668 & 0.643 & 0.504 & 0.504 & 0.833 & 0.861 & 0.456 & 0.477 & 0.377 & 0.657 & 0.786 & 0.769 \\
\hline$R_{435} / R_{500}$ & 0.612 & 0.402 & 0.196 & 0.342 & 0.255 & 0.242 & 0.312 & 0.194 & -0.241 & -0.050 & 0.095 & -0.101 \\
\hline$R_{435} / R_{620}$ & 0.533 & 0.345 & 0.174 & 0.297 & 0.172 & 0.164 & 0.331 & 0.199 & -0.125 & 0.068 & 0.108 & -0.123 \\
\hline$N D V I$ & -0.567 & -0.514 & -0.339 & -0.381 & -0.844 & -0.864 & -0.318 & -0.364 & -0.406 & -0.654 & -0.772 & -0.843 \\
\hline$S I$ & 0.140 & 0.201 & 0.147 & 0.074 & 0.611 & 0.633 & 0.089 & 0.165 & 0.561 & 0.550 & 0.527 & 0.716 \\
\hline$V I$ & -0.402 & -0.447 & -0.453 & -0.393 & -0.672 & -0.699 & -0.293 & -0.402 & -0.351 & -0.600 & -0.751 & -0.758 \\
\hline RESV & 0.669 & 0.689 & 0.543 & 0.543 & 0.826 & 0.866 & 0.376 & 0.447 & 0.157 & 0.438 & 0.707 & 0.732 \\
\hline$H M$ & 0.107 & 0.381 & 0.534 & 0.423 & 0.302 & 0.334 & 0.273 & 0.453 & 0.159 & 0.340 & 0.520 & 0.517 \\
\hline$C I$ & -0.153 & -0.284 & -0.266 & -0.185 & -0.594 & -0.623 & -0.113 & -0.234 & -0.395 & -0.419 & -0.552 & -0.711 \\
\hline$L C I$ & 0.465 & 0.462 & 0.351 & 0.316 & 0.811 & 0.835 & 0.250 & 0.314 & 0.411 & 0.576 & 0.704 & 0.829 \\
\hline$P I$ & -0.041 & -0.038 & -0.147 & -0.061 & -0.442 & -0.438 & 0.071 & -0.068 & -0.235 & -0.410 & -0.527 & -0.713 \\
\hline
\end{tabular}

Note. Correlation factors higher than 0.50 are marked with gray. 
ves and the accumulation of heavy metals in them.

The analysis of vegetation spectral indices and the content of heavy metals in the soils and leaves of the bioindicator plants has showed that these characteristics graphically change while moving from the central, less polluted park areas to the peripheral ones that are essentially affected by transport load.

The Mariinskyi Park has been established to be the most polluted. High content of heavy metals $\mathrm{Cu}, \mathrm{Pb}$, and $\mathrm{Cr}$ have been also found in the soils and leaves of plants from the KPI Park. The least polluted is the Feofanya park, because of its isolated location from the sources of pollution.

The spectral indices selected in the study can be recommended both for rapid assessment of the condition of park ecosystems, depending on the level of anthropogenic pollution, and for the interpretation of satellite images for zoning and assessing the degree of this pollution.

The considered method is promising and recommended for wide application in the environment monitoring system due to several practical advantages.

\section{REFERENCES}

1. Dmitriev, O. P. (Ed.). (2016). Bioindication of technogenic contamination in the city of Kyiv: methodological approaches. Kyiv [in Urainian].

2. Didukh, Ya. P. (2012). Basics of bioindication. Kyiv [in Ukrainian].

3. Iqbal, M. Z., Shafig, M., Qamar Zaidi, S., Athar, M. (2015). Effect of automobile pollution on chlorophyll content of roadsideurban trees. GlobalJ. Environ. Sci. Manage, 1 (4), 283-296. doi: 10.7508/gjesm.2015.04.003

4. Burda, R. I., Golivets, M. A., Petrovich, O. Z. (2014). Alien species in the flora of the nature reserve fund of the plain part of Ukraine. Russian journal. biol. invasion, 4, 1-29 [in Russian].

5. Samchuk, A. I., Kuraieva, I. V., Grodzynska, G. A., Vovk, K. V., Voitiuk, Yu. Iu., Zlobina, K. S., Stadnyk, V. O., Ohar, T. V., Nebesnyi, V. B., Honchar, H. Yu. (2019). Heavy metals in the environment of the Kyiv metropolis. Kyiv [in Ukrainian].

6. Kondratev, K. Ya., Fedchenko, P.P. (1982). Spectral Reflectance and Vegetation Recognition. Leningrad [in Russian].

7. Nebesnyy, V. B., Dubyna, D. V., Prokopenko, V. F., Shelyag-Sosonko Yu. R. (1993). Distribution of heavy metals accumulated inPhragmites australis in delta zones of the northern Black Sea coast. Hydrobiological Journal, 29, 9-21.

8. Levanchuk, A. V., Kopyitenkova, O. I., Nehoroshev, A. S., Gayko, I. I. (2005). The method of controlling the quality of the environment in a metropolis. Successes of modern science, 9, 59-61 [in Russian].

9. Andreeva, A. V., Buznikov, A. A., Skryabin, S. V., Timofeev, A. A., Alekseeva-Popova, N. V., Belyaeva, A. I. (2007). Investigation of the nature of changes in the optical characteristics of vegetation under the influence of heavy metals to develop a method for remote diagnosis of pollution. Modern Problems of Remote Sensing of the Earth from Space, 4 (2), 175-182 [in Russian].

10. Khavaninzadeh, A. R., Veroustraete, F., Buytaert, J. A. N., Dirckx, J., Samson, R. (2013). Assessing urban habitat quality using spectral characteristics of Tilia leaves. Environ. Pollut, 178, 7-14. doi: http://dx.doi.org/10.1016/j. envpol.2013.02.021.

11. Khavaninzadeh, A. R., Veroustraete, F., Buytaert, J. A. N., Samson, R. (2014). Leaf injury symptoms of Tilia sp. as an indicator of urban habitat quality. Ecological indicators, 41, 58-64.

12. Surin, V. G. (2011). Active optical testers for information support of precision farming, precision livestock breeding and environmental safety. Agrophysics, 2, 39-49 [in Russian].

13. Nebesnyi, V. B., Grodzynska, G. A. (2015). Estimation of technogenic pollution of Kyiv by spectral reflective characteristics of leaves Tilia cordata (Tiliaceae). Ukr. Botan.J., 72 (2), 116-121 [in Ukrainian].

14. Nebesnyi, V. B., Grodzynska, A. A., Honchar, H. Yu. (2016). Use of spectrophotometric method to assess the ecological condition of urban areas of Kyiv. Bulletin of the NAS of Ukraine, 8, 59-67 [in Ukrainian].

15. Nebesnyi, V. B., Grodzinskaya, A. A., Gonchar, A. Yu., Konyakin, S.M., Schur, K.Yu. (2016). The use of Tilia cordata Mill. as bioindicator for the evaluation of the ecological state of Kyiv urbanized areas (Ukraine). Journal of Medicinal Plants Studies, 4 (3), 277-282.

16. Nikolskiy, V. I. (1990). Dandelion as a possible object of phenological monitoring of natural ecosystems. Problems of biological systems stability: thesis of reports of the All-Union School. Kharkov [in Russian]. 
17. Stvolinskaya, N. S. (2000). Viability of Taraxacum officinale Wigg. in populations of the city of Moscow in connection with motor pollution. Ecology, 2, 147-150 [in Russian].

18. Pestova, L. V., Ryazantseva, O. V. (2004). Bioindication of motor pollution of urban areas. Polzunozsky Bulletin, 2, 87-94 [in Russian].

19. Nebesnyi, V., Grodzinskaya, A., Dugin, S. (2018, July). Using Remote Sensing Methods in Bioindication of Urban Ecosystems. Abstract eBook. The $4^{r d}$ International Symposium on EuroAsian Biodiversity (03-06 July, Kyiv). Kyiv.

20. Nebesnyi, V. B., Grodzinskaya, A. A., Samchuk, A. I. (2019, June). Bioindication of pollution by heavy metals of parking ecosystems of Kiev. Biogeochemistry - the scientific basis for sustainable development and protection of human health: proceedings of the XI International biogeochemical school (13-15June, Tula). Tula [in Russian].

21. Timofeev, A. A. (2009). Research and development of a method and a hardware-software complex for remote assessment of pollution of indicator species of vegetation by heavy metals. $\mathrm{Ph}$ (Teh.). Sankt-Peterburg [in Russian].

22. Cherepanov, A. S., Druzhinina, E. G. (2009). Spectral properties of vegetation and vegetation indices. Geomatika, 3, 28-32 [in Russian].

23. Roberts, D., Roth, K., Perroy, R. (2011). Hyperspectral vegetation indices. In: Hyperspectral Remote Sensing of Vegetation (Eds. Thenkabail, P.S., Huete, A.) CRC Press, Boca Raton, FL, US.

24. Iakymchuk, V. H., Lishchenko, L. P., Sukhanov, K. Yu., Porushkevych, A. Yu. (2015). Application of spectral indices of tree leaf spectrograms to assess the ecological conditions of their growth in Kyiv. Ukrainian Journal of Remote Sensing of the Earth, 5, 4-14 [in Ukrainian].

25. List of available Indices. https://www.index.database.de ((Last accessed: 27.12.2019).

26. Ponomarenko, O. M., Samchuk, A. I., Krasiuk, O. P., Makarenko, T. I., Antonenko, O. H. (2008). Analytical schemes of sample preparation of rocks and minerals and determination of microelements in them by the method of mass spectrometry with induction-coupled plasma (ISP-MS). Mineralogical journal, 4, 97-103 [in Ukrainian].

27. Grodzinskaya, A. A., Nebesnyi, V. B., Samchuk, A. I., Honchar, H. Yu. (2019). Radiocesium (137Cs) and Mineral Elements in Culinary-Medicinal Mushrooms from the Southern Outskirts of Kyiv, Ukraine. International Journal of Medicinal Mushrooms, 21 (1), P. 71-77. doi: 10.1615/IntJMedMushrooms.2018029583

Received 10.01.20

Revised 05.03.20

Accepted 17.03.20

\author{
В.Б. Небесний ${ }^{1}$, Г.А. Гродзинська ${ }^{1}$, \\ А.І. Самчук ${ }^{2}$, С.С. Дугін ${ }^{3}$, Г.Ю. Гончар ${ }^{1}$ \\ ${ }^{1}$ Інститут еволюційної екології НАН України, \\ вул. академіка Лебедєва, 37, Київ, 03143, Україна, \\ +380 44526 2051, info@ieenas.org \\ ${ }^{2}$ Інститут геохімії, мінералогії та рудоутворення ім. М.П. Семененка НАН України, \\ просп. академіка Палладіна, 34, Київ, 03142, Україна, \\ +380 44424 1270, office.igmr@gmail.com \\ ${ }^{3}$ Науковий Центр аерокосмічних досліджень Землі \\ Інституту геологічних наук Національної Академії Наук, \\ вул. О. Гончара, 55 б, Київ, 01054, Україна, \\ +380 44290 2601, casre@casre.kiev.ua

\section{СПЕКТРОФОТОМЕТРИЧНИЙ ЕКСПРЕС-МЕТОД} \\ БІОІНДИКАЦІЇ ПАРКОВИХ ЕКОСИСТЕМ
}

Вступ. Паркові зони виконують природоохоронні та рекреаційні функції в урбосередовищі, що знаходиться під впливом інтенсивного техногенного навантаження.

Проблематика. Глобальне зниження якості повітря, збільшення кількості токсичних викидів та відходів потребує проведення постійного моніторингу стану довкілля, орієнтованого, в першу чергу, на біотичні показники.

Мета. Оцінка стану техногенного забруднення паркових екосистем м. Києва за спектральними характеристиками листків біоіндикаторного виду Taraxacum officinale та вмістом важких металів в них та в грунтах з місцезростань.

Матеріали й методи. Метод спектрофотометрії для дослідження спектральних характеристик листків T. officinale; метод мас-спектрометрії з індукційно зв’язаною плазмою (ICP-MS) - для визначення вмісту Cu, $\mathrm{Pb}, \mathrm{Zn}, \mathrm{Mn}, \mathrm{Ni}, \mathrm{Cr}$ y листках та грунтах з локалітетів; статистичні методи. 
Результати. Показано середній рівень кореляційних зв'зків $(0,50-0,69)$ між вегетаційними індексами $R_{550} / R_{485}$, $R_{550} / R_{620}, R_{450} / R_{735}, N D V I, R E S V, S I$ та вмістом $\mathrm{Cu}, \mathrm{Pb}, \mathrm{Mn}$ у листках й $\mathrm{Pb}$ i $\mathrm{Mn}-$ у грунтах, та високий ступінь зв'язків $(0,75-0,87)$ між індексами $R_{450} / R_{735}, N D V I, R E S V, L C I$ та вмістом Zn i Cr у листках та грунтах. Встановлено чітку тенденцію зростання вмісту важких металів в напрямку від центральних частин паркових зон, до периферійних, що зазнають інтенсивного впливу транспортного навантаження. Найбільш забрудненим визначено Маріїнський парк. Високі рівні вмісту важких металів $\mathrm{Cu}, \mathrm{Pb}$ i $\mathrm{Cr}$ виявлені також в грунтах і листках рослин парку Київського політехнічного інституту. Найменший рівень забруднення має парк «Феофанія».

Висновки. Застосовані вегетаційні індекси рекомендовано як для експрес-оцінки стану природних і міських екосистем, так і для інтерпретації супутникових зображень з метою зонування та визначення ступеню техногенного забруднення. Використання спектрофотометричного методу для біоіндикації є перспективним завдяки швидкості отримання результатів, широті охоплення територій та низькій собівартості.

Ключові слова: біоіндикачія, важкі метали, паркові екосистеми, Taraxaсит оfficinale F.H.Wigg., спектральні відбивні характеристики. 